\title{
Vitamin D Deficiency Rickets in Infants Presenting with Hypocalcaemic Convulsions

\author{
Y Cesur ${ }^{1}$, SA Yuca ${ }^{1}$, A Kaya $^{1}$, C Yilmaz ${ }^{2}$, A Bay ${ }^{3}$
}

\begin{abstract}
Aim: Hypocalcaemia evaluation of the clinical, biochemical and radiological features of 91 infants with rickets who presented as hypocalcaemic convulsions.

Subjects and Methods: Ninety-one hypocalcaemic infants who were brought to hospital with convulsion and diag-nosed with rickets related to vitamin D deficiency according to their clinical, biochemical and radio-logical features were retrospectively reviewed.

Results: Mean values of the laboratory data were as follows: calcium $5.55 \pm 0.79 \mathrm{mg} / \mathrm{dL}$, phosphorus $4.77 \pm 1.66 \mathrm{mg} / \mathrm{dL}$, alkaline phosphatase $1525.5 \pm 925.4 \mathrm{U} / \mathrm{L}$ and parathormone $256.8 \pm 158.3 \mathrm{pg} / \mathrm{mL}$. Serum 25-OH vitamin D levels were below normal $(<20 \mathrm{ng} / \mathrm{mL})$ in 37 infants.

Conclusion: Vitamin D deficiency should be considered in infants presenting with hypocalcaemia. To avoid complications such as convulsions, clinicians should give vitamin D supplementation to such infants.
\end{abstract}

Keywords: Deficiency, hypocalcamic convulsion, infancy, vitamin D

\section{Raquitismo por Deficiencia de Vitamina D en Lactantes que Presentan Convulsiones por Hipocalcemia}

Y Cesur ${ }^{1}$, SA Yuca ${ }^{1}$, A Kaya ${ }^{1}$, C Yilmaz ${ }^{2}$, A Bay $^{3}$

\begin{abstract}
RESUMEN
Objetivo: Evaluación hipocalcémica de los aspectos clínicos, bioquímicos y radiológicos de 91 lactantes con raquitismo, que presentaron convulsiones por hipocalcemia.

Pacientes y métodos: Noventa y un lactantes hipocalcémicos llevados al hospital con convulsiones y a quienes se les diagnosticó raquitismo asociado a la deficiencia de vitamina $D$ de acuerdo con sus características, bioquímicas y radiológicas, fueron revisados retrospectivamente.

Resultados: Los valores medios de los datos de laboratorio fueron los siguientes: calcio $5.55 \pm 0.79$ $\mathrm{mg} / \mathrm{dL}$, fósforo $4.77 \pm 1.66 \mathrm{mg} / \mathrm{dL}$, fosfatasa alcalina $1525.5 \pm 925.4 \mathrm{U} / \mathrm{L}$, y paratohormona $256.8 \pm$ $158.3 \mathrm{pg} / \mathrm{mL}$. Los niveles séricos de la vitamina $25(\mathrm{OH})$ D estuvieron por debajo de lo normal en 37 lactantes $(<20 \mathrm{ng} / \mathrm{mL})$.

Conclusión: La deficiencia de vitamina $D$ debe considerarse en los infantes que se presentan con hipocalcemia. A fin de evitar complicaciones tales como convulsiones, se les debe dar suplementos de vitamina $D$.
\end{abstract}

Palabras claves: Deficiencia, convulsión hipocalcémica, infancia, vitamina D

West Indian Med J 2013; 62 (3): 201

From: ${ }^{1}$ Department of Pediatric Endocrinology, ${ }^{2}$ Department of Pediatric Neurology and ${ }^{3}$ Department of Pediatrics, Yüzüncü Yil University, Faculty of Medicine, Van, Turkey.

Correspondence: Dr A Kaya, Yüzüncü Yil University, Faculty of Medicine, Department of Pediatrics, Van, Turkey. Fax: +904322150479, e-mail: avnikaya@gmail.com

\section{INTRODUCTION}

Rickets usually occurs as a result of vitamin D deficiency. Less often, dietary deficiency of calcium $(\mathrm{Ca})$ or phosphorus (P) may also cause rickets (1). Vitamin D deficiency and/or nutritional rickets are still commonly seen in developing countries. In Turkey, nutritional rickets was detected in $6 \%$ of children less than three years of age and $3.1 \%$ in those under 
the age of 15 years $(2,3)$. According to our clinical experiences and the literature, there is an increase in the number of infants, who are brought with convulsion to Emergency Services and diagnosed with hypocalcemic rickets in recent times (4-6).

In this article, clinical, biochemical and radiological characteristics of 91 infants with vitamin D deficiency rickets presenting with hypocalcaemic seizures have been evaluated. The aim is to emphasize the importance of seizures in infants with rickets.

\section{SUBJECTS AND METHODS}

Ninety-one hypocalcaemic infants (70 boys, 21 girls), who were brought to hospital with seizures and diagnosed with vitamin D deficiency rickets according to their clinical, biochemical and radiological characteristics, were included in the study. Clinical and laboratory findings of the cases were reviewed retrospectively.

The biochemical criteria for rickets were defined as the following: low serum $25-\mathrm{OH}$ vitamin D level $(\leq 20 \mathrm{ng} / \mathrm{mL})$, increased serum alkaline phosphatase (ALP) and serum parathormone (PTH) levels or low serum Ca level (7). Rickets staging was performed according to the biochemical and radiographic findings (7). The nutritional status of children was evaluated by comparing weight measurements on a growth curve [Gomez standard] (8).

Intravenous calcium gluconate at a dose of $1 \mathrm{~mL} / \mathrm{kg}$ every six hours was given to all infants. After achieving normocalcaemia, it was switched to oral calcium lactate (50$75 \mathrm{mg} / \mathrm{kg}$ of elemental calcium per day in four divided doses).

There was pneumonia in nine patients, sepsis in five, acute gastroenteritis in one, hypoglycaemia in one and hypoxic-ischaemic encephalopathy in another. All patients were treated according to the underlying cause.

\section{RESULTS}

Most of the cases $(76.9 \%)$ were boys. The mean age was $6.01 \pm 4.06$ months (range 15 days -24 months). None of the cases had received vitamin D supplementation. Most patients were brought in the winter (41 (45\%) infants) and in spring (28 (30.7\%) infants). Another 12 (13.1\%) and 10 $(10.9 \%)$ infants were brought in autumn and summer, respectively. While $77(84.7 \%)$ infants had clinical findings of rickets (large anterior fontanel, large hand-wrist, rachitic rosary and craniotabes), no findings were recorded in 14 (15.3\%) cases. Mean laboratory values were as follows: $\mathrm{Ca}$ $5.55 \pm 0.79 \mathrm{mg} / \mathrm{dL}, \mathrm{P} 4.77 \pm 1.66 \mathrm{mg} / \mathrm{dL}$, alkaline phosphatase $1525.5 \pm 925.4 \mathrm{U} / \mathrm{L}$, and PTH $256.8 \pm 158.3 \mathrm{pg} / \mathrm{mL}$. Serum $P$ values were variable and only $30 \%$ of all cases were below the normal range (Tables 1,2).

Alkaline phosphatase and PTH values were high in most of the cases $(94.45 \%, 96.52 \%$, respectively). Serum 25 $\mathrm{OH}$ vitamin D levels were low in 37 patients $(<20 \mathrm{ng} / \mathrm{mL})$. $\mathrm{X}$-ray findings, which were variably consistent with rickets, were present in $36(75 \%)$ of 48 cases. According to biochemical and radiological findings, there was grade III rickets in $32.9 \%$ of cases over 12 months of age and grade I rickets in $67.1 \%$ less than three months of age; $30.5 \%$ of the patients were found to have protein-energy malnutrition (Table 3).

Vitamin D deficiency was the main cause in all of the patients. None of the patients had received vitamin D prophylaxis during infancy and their diet consisted mainly of breast or cow's milk.

Treatments used in 79 patients with treatment-related data are as follows: 300.000 IU in 45 (49.5\%), 150.000 IU in $22(24.2 \%)$, and $1000 \mathrm{IU} /$ day in $12(13.2 \%)$ [with mild radiological findings].

None of the infants had developed convulsions after initial therapy. At examination after six weeks, hypercalcaemia was diagnosed in one of 21 patients $(19.3 \mathrm{mg} / \mathrm{dL})$ receiving $1000 \mathrm{IU} /$ day vitamin D; in this patient, serum PTH level was suppressed $(4.7 \mathrm{pg} / \mathrm{mL})$. Since two cases did not show sufficient recovery (their ALP levels were still high even though $\mathrm{Ca}$ and $\mathrm{P}$ levels returned to normal), vitamin $\mathrm{D}$ treatment (1000 IU/daily) has continued.

Eighty-nine $(97.8 \%)$ episodes of seizures were generalized. Convulsion was localized in a single arm in two infants; laryngospasm was recorded in one infant. Most infants had more than one seizure before hospital admission.

Table 1: Biochemical values according to gender and patients' age at diagnosis

\begin{tabular}{|c|c|c|c|c|c|c|c|}
\hline Sex & $\begin{array}{l}n \\
(\%)\end{array}$ & $\begin{array}{c}\text { Age } \\
\text { (months) }\end{array}$ & $\underset{(\mathrm{mg} / \mathrm{dL})}{\mathrm{C}_{\mathrm{a}}}$ & $\begin{array}{c}\mathbf{P} \\
(\mathrm{mg} / \mathrm{dL})\end{array}$ & $\begin{array}{l}\text { ALP } \\
(\mathbf{U} / \mathbf{L})\end{array}$ & $\begin{array}{c}\text { PTH } \\
(\mathrm{pg} / \mathrm{mL})\end{array}$ & $\begin{array}{c}25 \mathrm{OH} \\
\text { vitamin } \mathrm{D}_{3} \\
(\mathrm{ng} / \mathrm{mL})\end{array}$ \\
\hline Female & $\begin{array}{c}21 \\
(23.1)\end{array}$ & $\begin{array}{c}7.48 \pm 5.16 \\
(\mathrm{n}=21)\end{array}$ & $\begin{array}{c}5.54 \pm 0.90 \\
(\mathrm{n}=21)\end{array}$ & $\begin{array}{c}4.61 \pm 1.82 \\
(\mathrm{n}=21)\end{array}$ & $\begin{array}{c}1574.2 \pm 1168,6 \\
(\mathrm{n}=21)\end{array}$ & $\begin{array}{c}270.0 \pm 181 \\
(\mathrm{n}=20)\end{array}$ & $\begin{array}{c}10.4 \pm 4.8 \\
(\mathrm{n}=9)\end{array}$ \\
\hline Male & $\begin{array}{c}70 \\
(76.9)\end{array}$ & $\begin{array}{c}5.57 \pm 4.18 \\
(\mathrm{n}=70)\end{array}$ & $\begin{array}{c}5.55 \pm 0.76 \\
(\mathrm{n}=70)\end{array}$ & $\begin{array}{c}4.82 \pm 1.63 \\
(\mathrm{n}=70)\end{array}$ & $\begin{array}{c}1510.7 \pm 847.5 \\
(\mathrm{n}=69)\end{array}$ & $\begin{array}{c}252.7 \pm 152.1 \\
(\mathrm{n}=66)\end{array}$ & $\begin{array}{c}9.60 \pm 5.19 \\
(\mathrm{n}=29)\end{array}$ \\
\hline Total & $\begin{array}{c}91 \\
(100)\end{array}$ & $\begin{array}{c}6.01 \pm 4.46 \\
(\mathrm{n}=91)\end{array}$ & $\begin{array}{c}5.55 \pm 0.79 \\
(\mathrm{n}=91)\end{array}$ & $\begin{array}{c}4.77 \pm 1.66 \\
(\mathrm{n}=91)\end{array}$ & $\begin{array}{c}1525.5 \pm 925.4 \\
(\mathrm{n}=90)\end{array}$ & $\begin{array}{c}256.8 \pm 158.3 \\
(\mathrm{n}=86)\end{array}$ & $\begin{array}{l}9.8 \pm 5.0 \\
(\mathrm{n}=38)\end{array}$ \\
\hline
\end{tabular}

$\mathrm{Ca}=$ calcium, $\mathrm{P}=$ phosphorus, $\mathrm{ALP}=$ alkaline phosphatase, $\mathrm{PTH}=$ parathormone 
Table 2: Classification of patients according to normal levels of biochemical data

\begin{tabular}{lcccc}
\hline Biochemical data & $\mathbf{n}$ & Measuring ranges & Category & $\mathbf{n}(\%)$ \\
\hline Calcium (mg/dL) & 91 & $<7.0$ & Low & $91(100.0)$ \\
Phosphorus (mg/dL) & 91 & $\begin{array}{c}<.8 \\
\text { (\%. }\end{array}$ & $\begin{array}{c}\text { Low } \\
\text { Normal }\end{array}$ & $\begin{array}{c}28(30.8) \\
(66.0)\end{array}$ \\
& & High & $12(13.2)$ \\
& & $<420$ & High & $85(94.5)$ \\
$\begin{array}{l}\text { Alkaline phosphatase } \\
(\mathrm{U} / \mathrm{L})\end{array}$ & 90 & $145-420$ & Normal & $5(5.5)$ \\
$\begin{array}{l}25(\mathrm{OH}) \text { vitamin } \mathrm{D}_{3} \\
(\mathrm{ng} / \mathrm{mL})\end{array}$ & 38 & $<20$ & Low & $37(97.3)$ \\
$\begin{array}{l}\text { Intact parathormone } \\
(\mathrm{pg} / \mathrm{mL})\end{array}$ & 86 & $20-50$ & Normal & $1(2.6)$ \\
& & $9-65$ & High & $83(96.5)$ \\
& & Normal & $3(3.5)$ \\
\hline
\end{tabular}

Vitamin D deficiency was the main cause in all of the patients. None of the patients had received vitamin D prophylaxis during infancy and had been fed usually with breast or cow's milk. Frequent childbirth of the patients' mothers, and malnutrition in their children were recorded as previously suggested in the literature, and babies and their mothers did not benefit enough from the sunlight $(16,17)$. In a study of 50 children manifesting with hypocalcaemic seizures, 13 cases of exclusively breastfed infants were confirmed to have vitamin D deficiency (18). Seizures have been observed even on the first days of life (19). Hypocalcemic convulsions may be severe enough to cause fractures. Bilateral femoral fracture had been reported in a 17year old male patient (20). None of the patients in this study had bone fractures.

Seizure due to congenital rickets is an unusual symptom during the first months of life. Hatun et al analysed

Table 3: Clinical and radiological findings of the patients by gender

\begin{tabular}{|c|c|c|c|c|c|c|c|}
\hline \multirow{2}{*}{$\begin{array}{c}\text { Sex } \\
\mathrm{n}(\%)\end{array}$} & \multicolumn{2}{|c|}{ Clinical signs } & \multicolumn{2}{|c|}{ Radiological signs } & \multicolumn{2}{|c|}{ Stage of rickets } & \multirow{2}{*}{$\begin{array}{c}\text { Protein-energy } \\
\text { malnutrition }\end{array}$} \\
\hline & None & Yes & None & Yes & I & III & \\
\hline $\begin{array}{c}\text { Female } \\
21(23.1)\end{array}$ & $\begin{array}{c}5(27.8 \%) \\
(\mathrm{n}=18)\end{array}$ & $\begin{array}{c}13(72.2 \%) \\
(\mathrm{n}=18)\end{array}$ & $\begin{array}{c}2(22.2 \%) \\
(\mathrm{n}=9)\end{array}$ & $\begin{array}{c}7(77.8 \%) \\
(\mathrm{n}=9)\end{array}$ & $15(71.5 \%)$ & $6(28.5 \%)$ & $\begin{array}{c}15(100 \%) \\
(\mathrm{n}=15)\end{array}$ \\
\hline $\begin{array}{c}\text { Male } \\
(\mathrm{n}=56)\end{array}$ & $\begin{array}{c}12(21.5 \%) \\
(\mathrm{n}=56)\end{array}$ & $\begin{array}{l}70(76.9) \\
(\mathrm{n}=39)\end{array}$ & $\begin{array}{c}10(25.6 \%) \\
(\mathrm{n}=39)\end{array}$ & $29(74.4 \%)$ & $46(65.8 \%)$ & $24(34.2 \%)$ & $\begin{array}{c}11(15.7 \%) \\
(\mathrm{n}=70)\end{array}$ \\
\hline $\begin{array}{c}\text { Total } \\
91(100)\end{array}$ & $\begin{array}{c}17(22.9 \%) \\
(\mathrm{n}=74)\end{array}$ & $\begin{array}{c}57(77.1 \%) \\
(\mathrm{n}=74)\end{array}$ & $\begin{array}{c}12(25 \%) \\
(\mathrm{n}=48)\end{array}$ & $\begin{array}{c}36(75 \%) \\
(\mathrm{n}=48)\end{array}$ & $61(67.1 \%)$ & $30(32.9 \%)$ & $\begin{array}{c}26(30.5 \%) \\
(\mathrm{n}=85)\end{array}$ \\
\hline
\end{tabular}

\section{DISCUSSION}

Hypocalcemia has been reported in the aetiology of neonatal convulsions for over a hundred years (9). The prevalence of neonatal convulsions was up to $33 \%$ in a large case series from Britain (10). Hypocalcaemic seizures are often generalized but can also appear as focal (11-13). While 89 $(97.8 \%)$ episodes of seizures of the patients were generalized, convulsion in two infants was localized in a single arm.

It is not definitely known why anticonvulsant drugs have no effect in hypocalcaemic seizures. Calcium plays multiple roles in normal neuronal functions. Calcium acts to induce neurotransmitter release through stimulus-sensitive coupling. The graded release of neurotransmitters requires an inward current through voltage-gated calcium channels. Calcium is known to allow mobilization of synaptic vesicles by phosphorylating synapses that subsequently allow the vesicles to be freed from the neuronal cytoskeleton and move to the active zone channels (14).

In a retrospective clinical survey of epidemiologic and clinical features in infants and children diagnosed with nutritional rickets over the last 10 years, tetany and seizure were detected in infants below the age of six months, failure to thrive was present in those aged 6-12 months, and skeletal deformities were determined in infants above the age of 12 years, as the most frequently recorded presentations (15). a total of 42 infants with vitamin D deficiency in the first three months of life and reported seizure (78.7\%) as the major presentation (21). Convulsion was noted in all of the patients. This fact may be explained by the low education attainment and low socio-economic status of families living in the Eastern Anatolia region of Turkey. Twenty-five $(27.3 \%)$ of the patients had protein-energy malnutrition.

Most patients in this study were admitted in winter (45\%) and spring (30.7\%). In our previous study, $31.7 \%$ of patients with hypocalcaemic seizures were seen in the spring, $11.0 \%$ in the summer, $20.7 \%$ in autumn and $36.6 \%$ in winter, frequently in January (2).

In the treatment of hypocalcaemia, calcium replacement is done. Typically, treatment with anticonvulsant drugs is not needed $(9,12)$. To maintain normocalcaemia, a continuous intravenous infusion of calcium (as elemental calcium, $20-80 \mathrm{mg} / \mathrm{kg} / 24$ hours) is preferable over frequent boluses as long as there is good intravenous access, since a large fraction of the calcium content in the bolus is lost in the urine during the infusion (22). Vitamin $\mathrm{D}$ should be given to infants with vitamin $\mathrm{D}$ deficiency rickets. The first regimen consists of daily therapy with 3000-5000 IU orally. An alternative treatment option in non-compliant patients or those without follow-up is "Stosstherapy"; a dose of 600000 IU of vitamin D is given orally in a single day if this method is chosen (23). However, a dose of 150000 IU or 300000 IU 
of vitamin $\mathrm{D}$ is adequate for the treatment of vitamin $\mathrm{D}$ deficiency rickets; moreover, 600000 IU of vitamin D may carry the risk of hypercalcaemia (24). Also, no statistically significant difference was found among the four different treatment options [150 000 IU, 300000 IU, 2000 IU for five to six months, and 5000 IU of vitamin D per day for three months] (2).

Initial finding in all of the patients was convulsion. All of them presented for the first time to a health centre with convulsions. None of them had been identified with hypocalcaemia in their routine controls or suffered convulsion thereafter. None of the patients developed convulsions after initial treatment.

The Ministry of Health of Turkey started a campaign in May 2005 to give free vitamin D supplements to all infants from 0-12 months across the country to eliminate nutritional rickets. Free vitamin D drops are distributed through health centres. According to clinical observations, the number of patients presenting with hypocalcaemic convulsions has declined in recent years.

The incidence of nutritional rickets in the 8631 children under three years of age in Eastern Anatolia in 1998 was found to be $6 \%$; in 2011 , the incidence was found to be $3.1 \%$ of 946 patients between four months and 15 years $(2,3)$. However, because of inadequate education of parents, a sufficient amount of vitamin D drops was not used. Therefore, we still encounter infants with rickets.

\section{CONCLUSION}

Vitamin D deficiency or nutritional rickets may present with convulsion without leading to evident clinical signs in infancy. Thus, although there are no clinical signs of rickets in hypocalcaemic infants, rickets should be considered and infants investigated for vitamin D deficiency; if the deficiency is confirmed, we wish to emphasize the need for vitamin D treatment.

\section{REFERENCES}

1. Chesney RW. Rickets: an old form for a new century. Pediatr Int 2003; 45: 509-11.

2. Cesur Y, Dogan M, Ariyuca S, Basaranoglu M, Bektas MS, Peker E et al. Evaluation of children with nutritional rickets. J Pediatr Endocrinol Metab 2011; 24: 35-43.

3. Ozkan B, Büyükavci M, Aksoy H, Tan H, Akdag R. Incidence of rickets among 0 to 3 -year old children in Erzurum. Cocuk Sağliği ve Hastaliklari Dergisi 1999; 42: 389-96. (in Turkish)
4. DeLucia MC, Mitnick ME, Carpenter TO. Nutritional rickets with normal circulating 25-hydroxyvitamin D: a call for reexamining the role of dietary calcium intake in North American infants. J Clin Endocrinol Metab 2003; 88: 3539-45.

5. Ladhani S, Srinivasan L, Buchanan C, Allgrove J. Presentation of vitamin D deficiency. Arch Dis Child 2004; 89: 781-4.

6. Tomashek KM, Nesby S, Scanlon KS, Cogswell ME, Powell KE, Parashar UD et al. Nutritional rickets in Georgia. Pediatrics 2001; 107: E45.

7. Shaw NJ. Vitamin D deficiency rickets. Endocr Dev 2003; 6: 93-104.

8. Gomez R, Ramos SF, Cravioto J, Chavez R, Vazquez J. Mortality in second and third degree malnutrition. J Trop Pediatr 1956; 2: 77-83.

9. Kossoff EH, Silvia MT, Maret A, Carakushansky M, Vining EP. Neonatal hypocalcemic seizures: case report and literature review. J Child Neurol 2002; 17: 236-9.

10. Keen JH. Significance of hypocalcaemia in neonatal convulsions. Arch Dis Child 1969; 44: 356-61.

11. Cockburn F, Brown JK, Belton NR, Forfar JO. Neonatal convulsions associated with primary disturbance of calcium, phosphorus, and magnesium metabolism. Arch Dis Child 1973; 48: 99-108.

12. Lynch BJ, Rust RS. Natural history and outcome of neonatal hypocalcemic and hypomagnesemic seizures. Pediatr Neurol 1994; 11: 23 7.

13. Oki J, Takedatsu M, Itoh J, Yano K, Cho K, Okuno A. Hypocalcemic focal seizures in a one-month-old infant of a mother with a low circulating level of vitamin D. Brain Dev 1991; 13: 132-4.

14. Kandel ER, Schwartz JH, Jessel TM. Principles of Neural Science. New York: McGraw-Hill; 2000.

15. Yeste D, Carrascosa A. Nutritional rickets in childhood: analysis of 62 cases. Med Clin (Barc) 2003; 121: 23-7.

16. Pugliese MT, Blumberg DL, Hludzinski J, Kay S. Nutritional rickets in suburbia. J Am Coll Nutr 1998; 17: 637-41.

17. Grover SR, Morley R. Vitamin D deficiency in veiled or dark-skinned pregnant women. Med J Aust 2001; 175: 251-2.

18. Balasubramanian S, Shivbalan S, Kumar PS. Hypocalcemia due to vitamin D deficiency in exclusively breastfed infants. Indian Pediatr 2006; 43: 247-51.

19. Erdeve O, Atasay B, Arsan S, Siklar Z, Ocal G, Berberoglu M. Hypocalcemic seizure due to congenital rickets in the first day of life. Turk J Pediatr 2007; 49: 301-3.

20. Schnadower D, Agarwal C, Oberfield SE, Fennoy I, Pusic M. Hypocalcemic seizures and secondary bilateral femoral fractures in an adolescent with primary vitamin D deficiency. Pediatrics 2006; 118: 2226-30.

21. Hatun S, Ozkan B, Orbak Z, Doneray H, Cizmecioglu F, Toprak D et al. Vitamin D deficiency in early infancy. J Nutr 2005; 135: 279-82.

22. Taketomo CK, ed. Lexi-Comp's Pediatric Dosage Handbook. $12^{\text {th }}$ ed. Washington: American Pharmaceutical Association; 2005: 224-8.

23. Shah BR, Finberg L. Single-day therapy for nutritional vitamin Ddeficiency rickets: a preferred method. J Pediatr 1994; 125: 487-90.

24. Cesur Y, Caksen H, Gundem A, Kirimi E, Odabas D. Comparison of low and high dose of vitamin D treatment in nutritional vitamin D deficiency rickets. J Pediatr Endocrinol Metab 2003; 16: 1105-9. 